\title{
Interaksi Komunikasi dalam Pendidikan
}

\begin{tabular}{|c|c|}
\hline \multicolumn{2}{|c|}{$\begin{array}{c}\text { Ahmad Taufik } \\
\text { STAI Bumi Silampari Lubuklinggau } \\
\text { ahmadtaufik201902@gmail.com }\end{array}$} \\
\hline Abstrak & \\
\hline $\begin{array}{l}\text { Article History } \\
\text { Received: } 15 \text { November } 2019 \\
\text { Revised :21 Desember } 2019 \\
\text { Accepted: } 25 \text { Desember } 2019 \\
\text { Keywords : } \\
\text { Communication, } \\
\text { Teacher, Interpersonal }\end{array}$ & $\begin{array}{l}\text { Through communication is the act } \\
\text { of carrying out contact between } \\
\text { the sender and the recipient, with } \\
\text { the help of a message; the sender } \\
\text { and recipient have several shared } \\
\text { experiences that give meaning to } \\
\text { the message and symbol sent by } \\
\text { the sender, and are received and } \\
\text { interpreted by the recipient. In the } \\
\text { world of education, } \\
\text { communication is carried out by } \\
\text { teachers and students. To create } \\
\text { effective communication. Almost } \\
\text { every time the teacher } \\
\text { communicates with teachers, } \\
\text { friends, and parents. } \\
\text { Communication with students will } \\
\text { be different from fellow teachers, } \\
\text { and parents. Communication skills } \\
\text { in question can be the ability to } \\
\text { understand and design } \\
\text { information, choose and use } \\
\text { channels or media, and } \\
\text { interpersonal communication skills } \\
\text { in the learning process. Learning } \\
\text { interactions must be created so } \\
\text { that students can be interested and } \\
\text { fun to learn. }\end{array}$ \\
\hline
\end{tabular}

\section{Pendahuluan}

Berdasarkan hal tersebut, pembelajaran merupakan suatu proses komunikasi. Komunikasi adalah proses pengiriman informasi dari satu pihak kepada pihak lain untuk tujuan tertentu. Komunikasi dikatakan efektif apabila komunikasi yang terjadi menimbulkan arus 
informasi dua arah, yaitu dengan munculnya feedback dari pihak penerima pesan. Kualitas pembelajaran dipengaruhi oleh efektif tidaknya komunikasi yang terjadi di dalamnya. Komunikasi efektif dalam pembelajaran merupakan proses transformasi pesan berupa ilmu pengetahuan dan teknologi dari pendidik kepada peserta didik, dimana peserta didik mampu memahami maksud pesan sesuai dengan tujuan yang telah ditentukan, sehingga menambah wawasan ilmu pengetahuan dan teknologi serta menimbulkan perubahan tingkah laku menjadi lebih baik. Pengajar adalah pihak yang paling bertanggungjawab terhadap berlangsungnya komunikasi yang efektif dalam pembelajaran, sehingga dosen sebagai pengajar dituntut memiliki kemampuan berkomunikasi yang baik agar menghasilkan proses pembelajaran yang efektif.

\section{Metode Penelitian}

Penulis dalam memberikan jawaban sesuai dengan fokus penelitian melalui metode kualitatif dengan kajian dokumen. Kajian dokumen dianggap sebagai analisis dokumen, yang terdiri buku, artikel, internet dan bahan-bahan yang sesuai dengan penelitian. Adapun cara-cara dalam pengumpulan datanya. Pertama, melalui kajian kepustakaan yang sesuai dengan bahan yang akan diteliti. Kedua, setelah datadata telah diperoleh oleh peneliti, maka selanjutnya menganalisis datanya melalui metode deskriptif sesuai dengan pemahaman penulis dalam melakukan kajian ini (Long, 2016).

\section{Pembahasan}

\section{Pengertian Komunikasi}

Menurut Kamus Besar Bahasa Indonesia, komunikasi adalah pengiriman dan penerimaan pesan atau berita antara dua orang atau lebih sehingga pesan yang dimaksud dapat dipahami. (Tim Penyusun Kamus Pusat Bahasa, 2002: 584)

Banyak pendapat dari berbagai pakar mengenai definisi komunikasi, namun jika diperhatikan dengan seksama dari berbagai pendapat tersebut mempunyai maksud yang hampir sama. Menurut Hardjana, sebagaimana dikutip oleh Endang Lestari (2003: 18) secara etimologis komunikasi berasal dari bahasa Latin yaitu cum, sebuah kata depan yang artinya dengan, atau bersama dengan, dan kata umus, sebuah kata bilangan yang berarti satu. Dua kata tersebut 
membentuk kata benda communio, yang dalam bahasa Inggris disebut communion, yang mempunyai makna kebersamaan, persatuan, persekutuan, gabungan, pergaulan, atau hubungan. Karena untuk bercommunio diperlukan adanya usaha dan kerja, maka kata communion dibuat kata kerja communicare yang berarti membagi sesuatu dengan seseorang, tukar menukar, membicarakan sesuatu dengan orang, memberitahukan sesuatu kepada seseorang, bercakap-cakap, bertukar pikiran, berhubungan, atau berteman. Dengan demikian, komunikasi mempunyai makna pemberitahuan, pembicaraan, percakapan, pertukaran pikiran atau hubungan. (Lestari, 2003: 48)

Weaver menyatakan bahwa komunikasi adalah seluruh prosedur melalui mana pikiran seseorang dapat mempengaruhi pikiran orang lain. (Widjaya, 2000: 26). Melalui komunikasi merupakan tindakan melaksanakan kontak antara pengirim dan penerima, dengan bantuan pesan; pengirim dan penerima memiliki beberapa pengalaman bersama yang memberi arti pada pesan dan simbol yang dikirim oleh pengirim, dan diterima serta ditafsirkan oleh penerima(Suranto, 2005: 30).

\section{Bentuk-bentuk Komunikasi}

Komunikasi intrapersonal

Komunikasi intrapersonal merupakan komunikasi dengan diri sendiri dengan tujuan untuk berfikir, melakukan penalaran, menganalisis dan merenung. Demikian menurut Effendy (1993:57) tentang pengertian komunikasi intrapersonal atau komunikasi antar pribadi merupakan komunikasi yang berlangsung dalam diri seseorang.orang itu berperan baik sebagai komunikator maupun sebagai komunikan. Komunikasi ini dianggap paling efektif dalam hal mengubah sikap, pendapat, atau perilaku seseorang, karena sifatnya dialogis berupa percakapan. Komunikasi interpersonal dampaknya dapat dirasakan pada waktu itu juga oleh pihak yang terlibat (Maria A.Rumanti, 2002: 52).

Komunikasi Antarpersonal

Komunikasi antarpersonal adalah proses pengiriman dan penerimaan pesan-pesan antara dua orang atau diantara sekelompok kecil orang-orang dengan beberapa efek dan beberapa umpan balik seketika. (Onong Uchjana Effendi, 1993: 57) 


\section{Komunikasi kelompok}

a. Komunikasi dalam kelompok besar (large group) Tidaklah selalu sama dengan komunikasi dalam kelompok kecil meskipun setiap kelompok besar pasti terdiri atas beberapa kelompok kecil. hal ini antara lain dikarenakan beberapa hal Komunikasi dalam kelompok besar jumlahnya yang besar (ratusan atau ribuan orang) di mana dalam suatu situasi komunikasi yang sedang berlangsung hampir tidak terdapat kesempatan untuk memberikan tanggapan secara verbal dan personal karna sedikit sekali kemungkinannya bagi komunikator untuk bertanggung jawab.

b. Situasi dialogis hampir tidak ada. Sebaiknya pembicara senantiasa perlu lebih fokus dalam arah pembicaraannya sehingga pendengar akan dapat mudah mencerna pesan pembicara.

c. Komunikasi kelompok kecil

Komunikasi kelompok kecil adalah sekumpulan perorangan yang relatif kecil yang masing-masing dihubungkan oleh beberapa tujuan yang sama dan mempunyai derajat organisasi tertentu diantara mereka. Contoh : komunikasi antar manager dengan sekumpulan karyawan

\section{Komunikasi Massa}

Komunikasi massa adalah produksi dan distribusi secara institusional dan teknologis dari sebagian besar aliran pesan yang dimiliki bersama secara berkelanjutan dalam masyarakat-masyarakat industrial. Komunikasi adalah interaksi yang dapat memberikan pemahaman. Dalam sebuah komunikasi ada proses dan usaha untuk memahami dan dipahami. Apabila kita bicara, tetapi belum dipahami oleh orang yang diajak bicara, maka dikatakan belum berkomunikasi. Itulah hakekat dari komunikasi. Dalam komunikasi terjadi interaksi dua arah, antara yang berbicara dan yang diajak bicara. Dalam dunia pendidikan, komunikasi dilakukan oleh guru dengan murid. Untuk menciptakan komunikasi yang efektif maka berusahalah untuk menghindari salah persepsi. Ada tiga hal yang perlu dalam berkomunikasi. Ketiga hal ini merupakan rangkaian yang tak terpisahkan, yaitu : 
a. Maksud yang hendak dikomunikasikan

Setiap kali guru hendak berkomunikasi, tentunya ada maksud tertentu. Apakah itu dalam bentk memberikan pengakuan, bimbingan, maupun perbaikan. Tentunya itu semua adalah untuk kepentingan anak didik dengan komunikasi itu terjadi perubahan ke arah yang lebih baik.

b. Cara mengomunikasikan

Meskipun mempunyai maksud yang baik, belum tentu komunikasi itu mampu mempengaruhi anak. Cara mengkomunikasikan masalah sangat menentukan kualitas komunikasi dan hasil yang diharapkan. Kadang-kadang maksud yang baik tetapi caranya kurang baik, maka diterima kurang baik. Sebaiknya, komunikasi dilakukan dengan cara yang baik.

c. Maksud bisa diterima

Bila cara komunikasi yang dilakukan oleh guru tepat, maka maksud yang hendak dikomunikasikan akan dapat diterima. Sebaiknya, bila cara mengomunikasikan informasi tidak tepat, maka informasi tidak sampai pada anak. (Najib Sulhan, 2010:152)

Komunikasi memegang peranan yang amat penting bagi kesuksesan seorang guru. Guru yang sukses mampu melakukan komunikasi yang efektif. Hampir setiap saat guru berkomunikasi dengan guru, teman, maupun orang tua. Komunikasi dengan siswa akan berbeda dengan sesama guru, dan orang tua. Adapun beberapa hal yang perlu diketahui ketika berkomunikasi dengan siswa. Komunikasi tidak selalu dengan bahasa verbal, bisa juga dilakukan dengan menggunakan bahasa nonverbal, yaitu bahasa tubuh, diantaranya : Ekspresi wajah, Tatapan mata, Gerak tubuh, Intonasi atau nada suara.

Komunikasi yang efektif dalam proses pembelajaran sangat berdampak terhadap keberhasilan pencapaian tujuan. Komunikasi dikatakan efektif apabila terdapat aliran informasi dua arah antara komunikator dan komunikan dan informasi tersebut sama-sama direspon sesuai dengan harapan kedua pelaku komunikasi tersebut. Jika dalam pembelajaran terjadi komunikasi yang efektif antara 
pengajar dengan mahasiswa, maka dapat dipastikan bahwa pembelajaran tersebut berhasil. Sehubungan dengan hal tersebut, maka para pengajar, pendidik, atau instruktur pada lembaga-lembaga pendidikan atau pelatihan harus memiliki kemampuan komunikasi yang baik. Kemampuan komunikasi yang dimaksud dapat berupa kemampuan memahami dan mendesain informasi, memilih dan menggunakan saluran atau media, serta kemampuan komunikasi antar pribadi dalam proses pembelajaran.

\section{Interaksi dalam Pendidikan}

Dalam Kamus Besar Bahasa Indonesia dijelaskan bahwa interaksi adalah hal saling melakukan aksi, berhubungan, mempengaruhi, antar hubungan. (Tim Penyusun Kamus Pusat Bahasa, 2002, 438) Pendidikan merupakan salah satu elemen terpenting dalam kehidupan manusia (Arikarani, 2016: 99). Pendidikan yang dapat diperoleh tidak hanya berasal dari sistem pendidikan formal melainkan bisa diperoleh dari lembaga-lembaga non formal bahkan dari keluarga. Pada saatpembelajaran otomatis terjadi interaksi antara murid dan guru, antara guru dan murid, serta murid dengan teman-temannya. Pola pergaulan yang baik sangat penting artinya bagi proses pendidikan seorang anak didik.

Guru sebagai tenaga profesional di bidang pendidikan, disamping memahami hal-hal yang bersifat filosofis dan konseptual, juga harus mengetahui dan melaksanakan hal-hal yang bersifat teknis. Hal-hal yang bersifat teknis ini, terutama kegiatan mengelola dan melaksanakan interaksi belajar mengajar. Dalam proses pendidikan sering kita jumpai kegagalan-kegagalan, hal ini biasanya dikarenakan lemahnya sistem komunikasi. Untuk itu, pendidik perlu mengembangkan pola komunikasi efektif dalam proses belajar mengajar.Komunikasi pendidikan yang penulis maksudkan disini adalah hubungan atau interaksi antara pendidik dengan peserta didik pada saat proses belajar mengajar berlangsung, atau dengan istilah lain yaitu hubungan aktif antara pendidik dengan peserta didik.

Namun, interaksi dalam kegiatan pembelajaran menjadi kurang maksimal ketika kegiatan pembelajaran didominasi oleh guru yang menjadi sumber informasi utama. Khususnya di dalam proses pembelajaran, interaksi antara guru dan anak didik sangatlah penting sebab kondisi anak didik yang beragam, kemampuan anak didik yang beragam. Jika guru hanya terfokus pada kegiatannya sendiri, maka 
akan terjadi blank (kekosongan) pada anak didik. Untuk itu, antara guru dan anak didik harus selalu berinteraksi, tidak hanya guru yang aktif melainkan anak didik juga harus aktif. Misalkan, jika anak didik merasa tidak mengerti materi pelajaran, maka seharusnya mereka mengatakannya pada guru sehingga guru mengerti bahwa ada anak didiknya yang belum mengerti dan guru dapat menjelaskan materi yang ia bawakan kembali. Ini adalah salah satu bentuk interaksi antar siswa guru.

Kurikulum saat ini seolah menuntut guru untuk menyelesaikan materi sesuai jadwal pendidikan yang terperinci dalam silabus seolah tanpa memerhatikan keadaan siswa. Sehingga sangat dilematis sekali jika harus mengajar terus-menerus. Tidak hanya itu, guru juga menjadi dilemma dalam menentukan cara yang baik untuk mengajar. Mengaktifkan hubungan timbal balik atau interaksi antara guru dan siswa itu merupakan syarat utama bagi berlangsungnya proses belajar mengajar. Interaksi dalam peritiwa belajar mengajar mempunyai arti yang lebih luas, tidak sekedar hubungan antara guru dengan siswa, tetapi berupa interaktif edukatif agar tujuan pembelajaran tercapai.

Adanya kesadaran bahwa proses belajar dan pembelajaran adalah merupakan proses komunikasi membawa implikasi-implikasi yang sangat penting dan mendasar bagi penyelenggaraan dan pelaksanaan serta hakikat proses belajar dan pembelajaran itu sendiri. Dimana Kegiatan pembelajaran dijadikan sebagai proses transformasi pesan edukatif berupa materi belajar. (Arief Sadiman, 1996: 24) Pembelajaran merupakan suatu sistem yang di dalamnya terdiri dari komponen-komponen sistem instruksional, yaitu komponen pesan, orang, bahan, peralatan, teknik, dan latar atau lingkungan. (Azhar Arsyad, 2009: 34)

Proses belajar mengajar dengan pola komunikasi ini mengarah pada proses pemebelajaran yang mengembangkan kegiatan siswa yang optimal, sehingga menumbuhkan siswa belajar aktif. (Syaiful Bahri Djamarah, 2004: 46) Setiap individu maupun kelompok mempunyai pola komunikasi yang berbeda-beda dan beragam. (Riswandi, 2013: 18) Untuk mencapai interaksi belajar mengajar sudah barang tentu adanya komunikasi yang jelas antara guru dengan siswa sehingga terpadunya dua kegiatan yakni kegiatan mengajar (usaha guru) dengan kegiatan belajar (tugas siswa) yang berdaya guna dalam mencapai pembelajaran. (Alo Liliweri, 1991: 46) 
Interaksi pembelajaran harus diciptakan sedemikian rupa sehingga anak didik bisa tertarik dan menyenangkan untuk belajar. Model pembelajaran juga harus tepat disesuaikan dengan materi dan tidak monoton. Keadaan seperti ini akan mengarah pada pencapaian hasil pembelajaran yang efektif. Sayangnya, kenyataan demikian terlihat bahwa pada saat penyajian materi guru lebih dominan di dalam kelas dengan menerapkan model pembelajaran langsung yang dikombinasikan dengan beberapa metode yaitu ceramah, diskusi, tugas dan tanya jawab. Akan tetapi metode pembelajaran langsung ini tidak secara keseluruhan dapat menarik minat, motivasi dan antusias siswa untuk belajar matematika. Suasana demikian cenderung membuat siswa diam dan pasif ditempat duduk mendengar dan menerima materi dari guru. Jika mengalami kesulitan dalam proses pembelajaran, siswa pada umumnya malu dan takut untuk bertanya kepada guru apalagi siswa yang berkemampuan rendah mereka cenderung diam dan enggan dalam mengemukakan pertanyaan atau pendapat. Hal ini secara langsung melumpuhkan interaksi yang seharusnya terjadi.

\section{Simpulan}

Dari penjelasan di atas dapat disimpulkan bahwa pembelajaran sebagai subset dari proses pendidikan harus mampu memberikan kontribusi terhadap peningkatan kualitas pendidikan, yang pada ujungnya akan berpengaruh terhadap peningkatan kualitas sumber daya manusia. Agar pembelajaran dapat mendukung peningkatan mutu pendidikan, maka dalam proses pembelajaran harus terjadi komunikasi yang efektif, yang mampu memberikan kefahaman mendalam kepada anak didik atas pesan atau materi belajar.

Komunikasi efektif dalam pembelajaran merupakan proses transformasi pesan berupa ilmu pengetahuan dan teknologi dari pendidik kepada anak didik, dimana anak didik mampu memahami maksud pesan sesuai dengan tujuan yang telah ditentukan, sehingga menambah wawasan ilmu pengetahuan dan teknologi serta menimbulkan perubahan tingkah laku menjadi lebih baik. Pendidik adalah pihak yang paling bertanggungjawab terhadap berlangsungnya komunikasi yang efektif dalam pembelajaran, sehingga dosen/guru sebagai pendidik dituntut memiliki kemampuan berkomunikasi yang baik agar menghasilkan proses pembelajaran yang efektif. 
Pada dasarnya kegiatan pembelajaran itu sendiri merupakan proses interaksi antara guru dan siswa/ anak didik. Salah satu hal yang memegang peranan penting bagi keberhasilan pembelajaran adalah proses pelaksanaannya. Pengajaran berintikan interaksi antar guru dengan siswa atau sebaliknya antara siswa dengan guru dalam proses belajar mengajar. Proses interaksi ini, guru melakukan kegiatan mengajar dan siswa belajar. Kegiatan mengajar dan belajar ini, bukan merupakan dua hal yang terpisah tetapi bersatu, dua hal yang menyatukannya adalah interaksi tersebut. 
132 Ahmad Taufik, Interaksi Komunikasi Dalam Pendidikan,.....

\section{DAFTAR PUSTAKA}

Tim Penyusun Kamus Pusat Bahasa. 2002. Kamus Besar Bahasa Indonesia. Pusat Bahasa: Jakarta.

Lestari. 2003. Komunikasi yang Efektif. Lembaga Administrasi Negara: Jakarta.

Suranto. 2005. Komunikasi Perkantoran. Media Wacana:Yogyakarta.

Effendi,Onong Uchjana. 1993. Ilmu Komunikasi ; Teori dan Praktek. Remaja Rosdakarya: Bandung.

Sulhan, Najib. 2010. Karakter Guru Masa Depan. JP Books: Surabaya.

Arsyad, Azhar. 2009. Media Pembelajaran. Grafindo: Jakarta.

Arikarani, Y. 2016. Analisis Kompetensi Supervisor dalam Bidang PAI di SMA Negeri 17 Kota Palembang. El-Ghiroh Vol 11 No 2 (September), 99-117, Retrieved from https://jurnal.staibsllg.ac.id/index.php/el-ghiroh/article/view/8

Sadiman, Arief. 1996. Media Pendidikan. Grafindo: Jakarta.

Liliweri, Alo. 1991. Komunikasi Antar Pribadi. Citra Aditya Bakti: Bandung.

Djamarah, Syaiful Bahri. 2004. Komunikasi Orangtua \& Anak dalam Keluarga. Rineka Cipta: Jakarta.

Rumanti, Maria. 2002.Dasar-dasar Public Relation Teori dan Praktis.Grasindo: Jakarta.

Riswandi. 2013. Psikologi Komunikasi. Graha Ilmu: Yogyakarta.

Widjaya. 2000. Ilmu Komunikasi Pengantar Studi. Rineka Cipta: Jakarta 